\title{
Pengaruh pemberian probiotik Lactobacillus helveticus Rosell-52 dan Lactobacillus rhamnosus Rosell-11 terhadap kadar limfosit lanjut usia
}

\author{
Retno Wahyuningsih ${ }^{1}$, Darmono $\mathrm{SS}^{2}$, Ani Margawati ${ }^{2}$
}

\begin{abstract}
Background: Infectious disease remains a health problem for the elderly. The elderly are susceptible to infection, because the body's ability to fight infection decreases immunity. The immune status can be improved through the efforts of immunization, and nutrition. However the elderly are not sufficient to meet the nutritional needs of food, so probiotic could support nutritional adequacy.

Objective: Analyze the effect of probiotic Lactobacillus helveticus Rosell-52 and Lactobacillus rhamnosus Rosell-11 on levels of lymphocytes in the elderly in Tresna Elderly Social Institution Puspakarma Mataram, West Nusa Tenggara.

Methods: This was quasi-experimental study, randomized pre-post control group design. The population is elderly aged 60-75 years, involving 45 subjects were divided randomly into two groups, namely the treatment groups given probiotics and the control group was given a placebo. Probiotics were given for 4 weeks, with the provision of one capsule a day. Immunity status in this study was lymphocytes. Data examined included the intake of nutrients (protein, vitamin A, vitamin $C$, vitamin $E$, $\mathrm{Fe}, \mathrm{Zn}$ ), health status, quality of sleep, and levels of lymphocytes in the elderly. Data were analyzed using bivariate with different test Independent sample t-test, Mann-Whitney U test, Spearman, Pearson, and Paired t-test.

Results: Increasing number of lymphocytes were significantly in the treatment group $(\chi \pm S D: 1.84 \pm 1.85)$ and in the control group (0.95 \pm 5.0$)$. There is no relationship between intake (protein, vitamin A, vitamin $C$, vitamin $E$, Fe, Zink), physical health status, and quality of sleep with levels of lymphocytes.
\end{abstract}

Conclusion: Probiotics in 4 weeks is proven to increase the number of lymphocytes in the elderly.

Key words: elderly, lymphocytes, immunonutrient intake, physical health status, quality of sleep.

\section{ABSTRAK}

Latar Belakang: Penyakit menular masih menjadi masalah kesehatan bagi lansia. Lansia rentan terhadap infeksi, karena kemampuan imunitas tubuh untuk melawan infeksi menurun. Status imunitas dapat ditingkatkan melalui imunisasi dan gizi. Pada lansia, pemenuhan zat gizi dari makanan saja tidak cukup untuk memenuhi kebutuhan gizi, sehingga probiotik dapat mendukung kecukupan gizi.

Tujuan: Menganalisis pengaruh probiotik Lactobacillus helveticus Rosell-52 dan Lactobacillus rhamnosus Rosell-11 terhadap kadar limfosit pada lansia di Lembaga Sosial Lansia Tresna Puspakarma Mataram, Nusa Tenggara Barat.

Metode: Penelitian ini merupakan penelitian kuasi-eksperimental dengan pre-post test with control group. Populasi adalah lansia berusia 60-75 tahun, yang melibatkan 45 subyek dibagi secara acak menjadi dua kelompok, yaitu kelompok perlakuan yang diberikan probiotik dan kelompok kontrol diberi plasebo. Probiotik diberi selama 4 minggu, dengan pemberian satu kapsul sehari. Status kekebalan dalam penelitian ini adalah limfosit. Variabel penelitian ini asupan zat gizi (protein, vitamin A, vitamin $C$, vitamin E, Fe, Zn), status kesehatan, kualitas tidur, dan tingkat limfosit pada orang tua. Data dianalisis dengan menggunakan uji beda independen t-test, uji Mann-Whitney $U$, dan Paired t-test. Uji bivariat dengan korelasi Pearson dan rank spearman.

Hasil: Peningkatan jumlah limfosit bermakna pada kelompok perlakuan ( \pm SD: $1.84 \pm 1.85$ ) dan pada kelompok kontrol

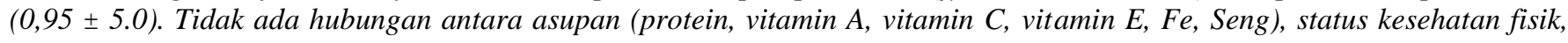
dan kualitas tidur dengan kadar limfosit.

Simpulan: Probiotik dalam 4 minggu terbukti dapat meningkatkan jumlah limfosit pada orang tua. Kata kunci: lansia, limfosit, asupan immunonutrien, status kesehatan fisik, kualitas tidur.

Kata kunci: lansia, limfosit, asupan immunonutrien, status kesehatan fisik, kualitas tidur.

\section{PENDAHULUAN}

Badan Pusat Statistik (BPS), menyatakan bahwa pada tahun 2010 lansia di Indonesia mencapai jumlah 24 juta $(9,8 \%)$ dari seluruh penduduk Indonesia, dan diperkirakan proporsi penduduk lansia akan meningkat dari $5 \%$ saat ini menjadi $8,5 \%$ di tahun

\footnotetext{
${ }^{1}$ Jurusan Gizi, Poltekkes Kemenkes Mataram, Nusa

Tenggara Barat, Indonesia

${ }^{2}$ Fakultas Kedokteran Universitas Diponegoro Indonesia
}

2025.Menurut Undang-undang Nomor 13 tahun 1998 tentang Kesejahteraan Lanjut Usia, yang dimaksud dengan lanjut usia adalah penduduk yang berusia 60 tahun ke atas. ${ }^{1}$

Lanjut usia mengalami penurunan fungsi organ, hal ini disebabkan oleh adanya faktor alamiah maupun penyakit, sehingga berdampak pada berbagai aspek kehidupan lansia, baik sosial, ekonomi, dan kesehatan. ${ }^{1}$ Penurunan kondisi kesehatan lansia akan mengakibatkan angka kesakitan semakin meningkat. 
BPS mencatat bahwa angka kesakitan lansia di Indonesia

cenderung meningkat, yakni pada tahun 2005 sebesar 29,98\%, dan tahun 2007 sebesar 31,11\%. Angka kesakitan penduduk lansia tertinggi terdapat di Prov. Aceh $(41,74 \%)$, Nusa Tenggara Barat $(39,19 \%)$ dan Gorontalo $(38,16 \%) .^{2}$

Salah satu yang menjadi perhatian khusus pada kesehatan lansia adalah masalah penyakit infeksi. Lansia rentan terhadap infeksi, dikarenakan kemampuan imunitas tubuh melawan infeksi menurun. Salah satu komponen utama sistem kekebalan tubuh adalah limfosit yang berperan dalam pengenalan dan penghancuran sel yang terinfeksi virus. Kelompok lansia kurang mampu menghasilkan limfosit untuk sistem imun. Sel perlawanan infeksi yang dihasilkan kurang cepat bereaksi dan kurang efektif daripada sel yang ditemukan pada kelompok dewasa muda. ${ }^{1}$

Sistem imunitas tubuh dapat ditingkatkan melalui upaya imunisasi dan asupan gizi. Asupan gizi berperan penting dalam peningkatan respon imun. Lansia tidak cukup memenuhi kebutuhan gizinya melalui asupan makan, karena ada gangguan selera makan, penurunan kemampuan mengunyah, adanya penyakit, dan jumlah gigi yang mulai berkurang. Asupan gizi yang kurang, akan berpengaruh pada penurunan sistem kekebalan tubuh lansia, sehingga diperlukan dukungan gizi selain dari asupan makanan. Dukungan gizi tersebut dapat berupa pemberian suplemen protein, vitamin, mineral, dan probiotik. . $^{1,3,4}$

Dewasa ini, kesadaran masyarakat terhadap tindakan preventif pada kesehatan dengan mengkonsumsi probiotik semakin meningkat. Hal tersebut diiringi dengan munculnya beragam produk probiotik (minuman, kapsul, tablet). Promosi mengenai probiotikpun semakin gencar dengan disertai klaim yang mengindikasikan kearah pengobatan dan manfaatnya terhadap kesehatan, namun sejauh ini masih sedikit bukti penelitian yang menunjukkan manfaat dan keberhasilan suplemen probiotik dalam meningkatkan kesehatan lansia.

Probiotik didefinisikan sebagai bakteri hidup yang diberikan sebagai suplemen makanan yang mempunyai pengaruh menguntungkan terhadap kesehatan yakni bermanfaat dalam meningkatkan sistem kekebalan tubuh, memperbaiki penyerapan gizi makanan, memperlambat proses degeneratif alamiah akibat perkembangan bakteri-bakteri merugikan dalam sistem pencernaan, dan memperkuat fungsi usus dengan menjaga keseimbangan flora usus. ${ }^{4}$ Produkproduk probiotik yang beredar di pasaran saat ini, menggunakan bakteri dari Lactobacillus. Beberapa spesies Lactobacillus yang digunakan dalam suplemen probiotik yaitu $L$. helveticus dan $L$. rhamnosus. Dua milyar $c f u$ organisme yang terdiri dari $L$. helveticus
Rosell-52 dan L. rhamnosusRosell-11 memiliki peranan dalam memelihara kesehatan fungsi pencernaan.

Permasalahan yang diteliti yaitu apakah ada pengaruh pemberian probiotik $L$. helveticusRosell-52 dan L. rhamnosusRosell-11 terhadap kadar limfosit pada lansia di PSTWPuspakarmaMataram. Penelitian ini bertujuan untuk mengetahui pengaruh pemberian probiotik $L$. helveticusRosell-52 dan $L$. rhamnosusRosell-11 terhadap kadar limfosit pada lansia di PSTW Puspakarma Mataram, Prov. NTB.

\section{METODE DAN BAHAN}

\section{Desain, Waktu dan Tempat}

Metode penelitian adalah eksperimen semu (quasi experiment) dengan rancangan randomized pre-post test control group design. Penelitian

Subjek menggunakan dua kelompok, yakni kelompok perlakuan diberikan probiotik, dan kelompok kontrol diberikan placebo.Penelitian dilakukan pada bulan Desember 2013-Januari 2014 di Panti Puspakarma Mataram Prov. NTB.

\section{Subjek Penelitian}

Subjek dalam penelitian ini adalah lansia yang tinggal di PSTW Puspakarma Mataram, dengan kriteria inklusi berusia 60-75 tahun, dan bersedia menjadi responden penelitian dengan menandatangani informed consent. Perhitungan besar sampel minimal dengan menggunakan tingkat kesalahan $(\alpha)=5 \%$, power test $=90 \%$ standar deviasi dari penelitian Panggabean $=3.10 \%$, dengan nilai $\left(\mu_{1}-\mu_{2}\right)=3.22,{ }^{5}$ untuk antisipasidrop out ditambah $10 \%$ sehingga total minimal subjek penelitian yang dibutuhkan adalah sebanyak 46 orang.Lansia yang memenuhi kriteria inklusi, dibagi secara simple random sampling, yakni membaginya menjadi perlakuan dan kontrol.

\section{Bahan Intervensi}

Bahan intervensi yakni probiotik mengandung 2 milyar cfu terdiri dari Lactobacillus helveticusRosell52 dan Lactobacillus rhamnosusRosell-11 (kapsulmerk dagang Lacidofil ${ }^{\mathrm{TM}}$ ) dan placebo. Bentuk dan ukuran kedua suplemen dibuat dalam kemasan yang sama.

\section{Cara Pengumpulan Data}

Data status gizi berupa IMT pada subjek penelitian dilakukan dengan pengukuran antropometri tinggi lutut (dikonversikan ke tinggi badan) dan berat badan . Kebutuhan gizi diperoleh dari hasil perhitungan menurut kebutuhan perindividu. Data asupan gizi diperoleh dari konsumsi makanan yang dikumpulkan dengan metode foodweighing. Data kualitas tidur diperoleh dari hasil wawancara dengan formulir PSQI (Pittsburgh Sleep Quality Index). Data status 
kesehatan diperoleh dari pencatatan hasil laporan bulanan panti. Kadar limfositdiperoleh dari hasil pemeriksaan darah dengan menggunakan metode hematologyanalyser.

\section{Pengolahan dan Analisis Data}

Data dianalisis dengan menggunakan uji independent t-test, whitney u-test, dan paired t-test. Analisis untuk mengetahui hubungan variabel bebas menggunakan uji Pearson dan Spearman.

\section{HASIL}

Subjek yang digunakan dalam penelitian sebanyak 46 lansia, terbagi dua kelompok, yakni kelompok perlakuan dengan pemberian probiotik sebanyak 23 lansia dan kelompok kontrol dengan pemberian placebo sebanyak 23 lansia. Hari ke-15 penelitian berlangsung, terdapat satu lansia dari kelompok placebo yang drop out, hal ini dikarenakan responden meninggal, sehingga total responden yang digunakan sampai akhir penelitian sebanyak 45 lansia.

Tabel 1. Karakteristik Subjek Berdasarkan Kelompok

\begin{tabular}{|c|c|c|c|c|c|}
\hline \multirow{3}{*}{ Karakteristik } & \multicolumn{4}{|c|}{ Kelompok } & \multirow{3}{*}{$\mathrm{p}$} \\
\hline & \multicolumn{2}{|c|}{ Perlakuan $(n=23)$} & \multicolumn{2}{|c|}{ Kontrol $(n=22)$} & \\
\hline & $\mathrm{n}$ & $\%$ & $\mathrm{n}$ & $\%$ & \\
\hline \multicolumn{6}{|l|}{ Umur (th) } \\
\hline $61-65$ & 6 & 26.1 & 6 & 27.3 & \\
\hline $66-70$ & 11 & 47.8 & 5 & 22.7 & $0.247^{\mathrm{a}}$ \\
\hline $71-75$ & 6 & 26.1 & 11 & 50 & \\
\hline Rerata \pm SD & \multicolumn{2}{|c|}{$69.0 \pm 4.36$} & \multicolumn{2}{|c|}{$70.5 \pm 4.98$} & \\
\hline \multicolumn{6}{|l|}{ Jenis Kelamin } \\
\hline Laki-laki & 9 & 39.1 & 8 & 36.4 & $0.848^{b}$ \\
\hline Perempuan & 14 & 60.9 & 14 & 63.6 & \\
\hline Rerata \pm SD BB Awal (kg) & \multicolumn{2}{|c|}{$48.7 \pm 6.89$} & \multicolumn{2}{|c|}{$46.8 \pm 10.66$} & $0.276^{\mathrm{a}}$ \\
\hline Rerata \pm SDBB Akhir (kg) & \multicolumn{2}{|c|}{$50.1 \pm 6.74$} & \multicolumn{2}{|c|}{$47.5 \pm 10.45$} & $0.212^{\mathrm{a}}$ \\
\hline \multicolumn{6}{|l|}{ IMT Awal $\left(\mathrm{Kg} / \mathrm{m}^{2}\right)$} \\
\hline Kurang $(<18.5)$ & 5 & 21.7 & 12 & 54.5 & \\
\hline Normal (18.5-22.9) & 12 & 52.1 & 6 & 27.3 & $0.156^{\mathrm{a}}$ \\
\hline Lebih $(\geq 23)$ & 6 & 26.1 & 4 & 18.2 & \\
\hline Rerata $\pm S D$ & \multicolumn{2}{|c|}{$20.0 \pm 3.13$} & \multicolumn{2}{|c|}{$17.9 \pm 3.98$} & \\
\hline
\end{tabular}

Tabel 2. Asupan dan Tingkat Konsumsi Zat-zat Gizi Lansia

\begin{tabular}{|c|c|c|c|c|c|}
\hline \multirow{3}{*}{ Variabel } & \multicolumn{4}{|c|}{ Kelompok } & \multirow{3}{*}{$\mathrm{p}$} \\
\hline & \multicolumn{2}{|c|}{ Perlakuan } & \multicolumn{2}{|c|}{ Kontrol } & \\
\hline & Rerata & SD & Rerata & SD & \\
\hline \multicolumn{6}{|l|}{ Asupan } \\
\hline Energi (kal) & 1623.33 & 77.52 & 1618.89 & 147.26 & $0.555^{\mathrm{a}}$ \\
\hline Protein (g) & 51.70 & 2.69 & 50.40 & 4.43 & $0.036^{\mathrm{a}}$ \\
\hline Vitamin A $(\mu \mathrm{g})$ & 514.60 & 23.52 & 496.90 & 38.09 & $0.018^{\mathrm{a}}$ \\
\hline Vitamin C (mg) & 29.60 & 4.22 & 29.70 & 11.88 & $0.570^{\mathrm{a}}$ \\
\hline Vitamin E (mg) & 4.30 & 0.43 & 4.20 & 0.40 & $0.261^{\mathrm{a}}$ \\
\hline $\mathrm{Fe}(\mathrm{mg})$ & 8.50 & 0.42 & 8.70 & 0.76 & $0.724^{\mathrm{a}}$ \\
\hline Zink (mg) & 5.40 & 0.27 & 5.40 & 0.51 & $0.219^{\mathrm{a}}$ \\
\hline \multicolumn{6}{|c|}{ Tingkat Konsumsi (\%) } \\
\hline Energi & 88.06 & 9.53 & 87.58 & 10.53 & $0.871^{b}$ \\
\hline Protein & 107.69 & 16.92 & 105.81 & 16.64 & $0.709^{b}$ \\
\hline Vitamin A & 112.16 & 18.79 & 110.71 & 20.50 & $0.805^{\mathrm{b}}$ \\
\hline Vitamin C & 44.40 & 7.89 & 43.65 & 20.03 & $0.928^{a}$ \\
\hline Vitamin E & 32.69 & 6.68 & 31.39 & 8.57 & $0.571^{b}$ \\
\hline $\mathrm{Fe}$ & 81.92 & 13.99 & 82.69 & 13.56 & $0.851^{b}$ \\
\hline Zink & 112.97 & 22.02 & 112.70 & 21.97 & $0.967^{\mathrm{b}}$ \\
\hline
\end{tabular}

Keterangan : $\mathrm{a}=$ Mann whitney $u$-test $: b=$ Independent sample $t$-test 


\section{Karakteristik Subjek Penelitian}

Sebagian besar subjek dalam penelitian ini adalah lansia yang berumur 71-75 tahun (50\%) pada kelompok kontrol dan umur 66-70 tahun $(47,8 \%)$ pada kelompok perlakuan, jenis kelamin perempuan yakni sebesar $63.6 \%$ pada kelompok kontrol dan 60,9\% pada kelompok perlakuan.

Tabel 1 menunjukkan tidak terdapat perbedaan antara rerata umur, BB awal, BB akhir, dan indeks massa tubuh (IMT) awal. Sebagian besar responden pada kelompok perlakuan memiliki status gizi normal $(52,1 \%)$, sedangkan kelompok kontrol sebagian besar memiliki status gizi kurang (54.5\%).

Berdasarkan Tabel 2, tidak ada beda asupan energi, vitamin $\mathrm{C}$, vitamin $\mathrm{E}, \mathrm{Fe}$, dan zink pada kedua kelompok, sedangkan pada asupan protein dan vitamin A terdapat beda pada kedua kelompok. Hasil analisis untuk tingkat konsumsi energi, protein, vitamin $\mathrm{A}$, vitamin $\mathrm{C}$, vitamin $\mathrm{E}$, Fe, Zink menunjukkan tidak beda antara kedua kelompok.

\section{Kualitas Tidur Lansia}

Kualitas tidur lansia dinilai dengan menggunakan formulir Pittsburgh Sleep Quality Index (PSQI) yang terdiri dari 18 item pertanyaan. Secara keseluruhan kualitas tidur lansia tergolong cukup baik. Lansia di panti paling banyak membutuhkan waktu untuk tertidur sekitar 31-60 menit (kelompok perlakuan), dan $\leq 15$ menit (kelompok kontrol). Sebagian besar lansia di panti mempunyai durasi tidur 6-7 jam perhari, kebiasaan tidur lansia sangat efisien.Lansia mengalami gangguan tidur di malam hari sebanyak 12 kali dengan total skor gangguan 10-18, umumnya lansia tidak menggunakan obat tidur dan tidak mengalami gangguan aktivitas di siang hari.

\section{Status Kesehatan Fisik}

Sebagian besar lansia memiliki status kesehatan fisik yang sehat. Lansia yang tidak sehat, beberapa diantaranya menderita penyakit DM, Hipertensi, Anemia, dan Osteoartritis (Tabel 4).

\section{Pemeriksaan Kadar Limfosit}

Rerata limfosit di awal penelitian lebih rendah dibandingkan dengan rerata limfosit di akhir penelitian, hal ini terjadi pada dua kelompok penelitian. Hasil uji statistik menunjukkan tidak ada beda limfosit antara kedua kelompok, baik di awal penelitian, akhir penelitian maupun perubahan limfosit awal dan akhir.Hasil uji statistik pada kelompok perlakuan menunjukkan ada perubahan yang signifikan antara limfosit awal dan akhir (Tabel $5)$.

\section{Hubungan antara Asupan Makan, Kualitas Tidur, Status Kesehatan Fisik dengan Limfosit}

Hasil uji statistik menunjukkan tidak ada hubungan antara asupan makan, kualitas tidur, status kesehatan fisik dengan limfosit.

Tabel 3. Kualitas Tidur Lansia

\begin{tabular}{lccccc}
\hline \multirow{2}{*}{$\begin{array}{c}\text { Kualitas } \\
\text { Tidur }\end{array}$} & \multicolumn{4}{c}{ Kelompok } & \\
\cline { 2 - 5 } & \multicolumn{2}{c}{ Perlakuan $(\mathrm{n}=23)$} & \multicolumn{2}{c}{ Kontrol $(\mathrm{n}=22)$} & \multirow{2}{*}{$\mathrm{p}$} \\
\cline { 2 - 5 } & $\mathrm{n}$ & $\%$ & $\mathrm{n}$ & $\%$ & \\
\hline Baik & 11 & 47.8 & 11 & 50 & \multirow{2}{*}{$0.885^{\mathrm{a}}$} \\
Tidak Baik & 12 & 52.2 & 11 & 50 & \\
\hline Jumlah & 23 & 100 & 22 & 100 & \\
\hline
\end{tabular}

Keterangan $: \mathrm{a}=$ Mann whitney $u$-test

Tabel 4. Status Kesehatan Fisik

\begin{tabular}{lccccc}
\hline \multirow{3}{*}{ Kesehatan } & \multicolumn{5}{c}{ Kelompok } \\
\cline { 2 - 6 } & \multicolumn{2}{c}{ Perlakuan $(\mathrm{n}=23)$} & \multicolumn{2}{c}{ Kontrol $(\mathrm{n}=22)$} & \multirow{2}{*}{$\mathrm{P}$} \\
& $\mathrm{n}$ & $\%$ & $\mathrm{n}$ & $\%$ & \\
\hline Sehat & 17 & 73.9 & 12 & 54.5 & \multirow{2}{*}{$0.180^{\mathrm{a}}$} \\
Tidak Sehat & 6 & 26.1 & 10 & 24.5 & \\
\hline Jumlah & 23 & 100 & 22 & 100 & \\
\hline
\end{tabular}

Keterangan : $\mathrm{a}=$ Mann whitney $u$-test 
Tabel 5. Hasil Pemeriksaan Kadar Limfosit

\begin{tabular}{lccc}
\hline \multirow{2}{*}{$\begin{array}{l}\text { Kadar Limfosit } \\
\text { (\%) }\end{array}$} & \multicolumn{2}{c}{ Kelompok } & \\
\cline { 2 - 3 } & \multicolumn{2}{c}{ Perlakuan $(\mathrm{n}=23)$} & Kontrol $(\mathrm{n}=22)$ \\
\cline { 2 - 3 } & & \\
\hline Awal & $35.95 \pm 6.52$ & $35.00 \pm 7.56$ & $0.653^{\mathrm{a}}$ \\
Akhir & $37.80 \pm 6.99$ & $35.95 \pm 8.08$ & $0.416^{\mathrm{a}}$ \\
$\Delta$ & $1.84 \pm 1.85$ & $0.95 \pm 5.01$ & $0.428^{\mathrm{a}}$ \\
$\mathrm{p}$ & $0.000^{\mathrm{b}}$ & $0.384^{\mathrm{b}}$ & \\
\hline
\end{tabular}

Keterangan : $\mathrm{a}=$ Independent sample $t$-test, $\mathrm{b}=$ Paired $t$-tes

Tabel 6. Hubungan Asupan Makan, Kualitas Tidur, dan Status Kesehatan Fisik dengan Limfosit

\begin{tabular}{ll}
\hline \multicolumn{1}{c}{ Variabel } & Nilai p \\
\hline Asupan Protein & $0.689^{\mathrm{a}}$ \\
Asupan Vitamin A & $0.650^{\mathrm{a}}$ \\
Asupan Vitamin C & $0.404^{\mathrm{a}}$ \\
Asupan Vitamin E & $0.718^{\mathrm{a}}$ \\
Asupan Fe & $0.777^{\mathrm{a}}$ \\
Asupan Zn & $0.358^{\mathrm{a}}$ \\
Kualitas Tidur & $0.738^{\mathrm{b}}$ \\
Status Kesehatan & $0.649^{\mathrm{b}}$ \\
\hline
\end{tabular}

Keterangan : $\mathrm{a}=\mathrm{Uji}$ Pearson, $\mathrm{b}=\mathrm{Uji}$ Spearman

\section{PEMBAHASAN}

Tidak ada beda asupan dan tingkat konsumsi zat gizi pada dua kelompok dikarenakan lansia hanya mengkonsumsi makanan dari dalam panti. Ketersediaan makanan yang diberikan oleh panti, juga termasuk kurang bervariasi, misalnya dari 10 hari siklus menu yang disediakan di panti, setiap harinya hampir dijumpai menu makanan yang sama.

Terjadi kecenderungan konsumsi makan yang kurang pada lansia di panti, hal ini sejalan dengan hasil riset kesehatan dasar (Riskesdas) menyatakan bahwa rata-rata tingkat kecukupan energi usia 56 tahun ke atas hanya mencapai $86,9 \% .^{6}$ Konsumsi energi dan zat gizi pada lansia umumnya mulai mengalami penurunan hal ini antara lain disebabkan karena berkurangnya nafsu makan akibat menurunnya indera pengecap, penurunan kemampuan mengunyah dan jumlah gigi yang mulai berkurang, kesulitan dalam mengolah makanan akibat kondisi fisiologis, serta rendahnya ketersediaan pangan karena faktor ekonomi dan lingkungan. ${ }^{7,8}$

Secara keseluruhan kualitas tidur lansia tergolong cukup baik. Kualitas tidur dapat dipengaruhi oleh beberapa faktor yaitu : lingkungan, penyakit fisik, kelelahan, gaya hidup, stres emosional, diet, merokok, dan medikasi. ${ }^{9}$ Gangguan tidur pada orang tua dapat melemahkan sistem imun, yakni sel NK. Sel NK adalah bagian dari sistem imun tubuh, jika jumlahnya menurun maka dapat melemahkan imunitas sehingga rentan terhadap penyakit. Studi penilaian kualitas tidur menunjukkan pentingnya tidur bagi orang tua untuk memelihara kesehatan tubuh. Tidur yang baik tidak hanya dapat meningkatkan kesehatan secara keseluruhan, tetapi juga dapat mencegah hasil fisiologis dan psikologis yang buruk berhubungan dengan peradangan. ${ }^{10}$

Penyakit yang berhubungan dengan usia dan keadaan yang menyertai bukan hanya meningkatkan kerentanan orang lanjut usia terhadap infeksi tetapi juga dapat menekan respon imun lansia. Penyakit metabolisme dan infeksi yang menyebabkan gangguan sistem imunitas antara lain : diabetes mellitus, tuberkulosis, osteoartritis, gangguan ginjal, gangguan hati menahun. ${ }^{11}$

Hasil uji statistik menunjukkan $(\mathrm{p}=0.000)$, dapat disimpulkan bahwa ada perubahan yang signifikan antara limfosit awal dan akhir. Pemberian probiotik Lactobacillus helveticus Rosell-52 dan Lactobacillus rhamnosus Rosell-11 terbukti memberikan hasil yang signifikan terhadap kenaikan limfosit pada lansia, sejalan dengan penelitian yang dilakukan oleh Gill bahwa pemberian probiotik Bifidobacterium lactis HN0191 meningkatkan sel helper (CD4+) dan (CD25+), limfosit dan sel NK pada lansia sehat. ${ }^{12}$

Konsumsi probiotik memiliki potensi manfaat yang besar bagi individu dengan sistem kekebalan tubuh yang kurang berfungsi, terutama pada lansia yang mengalami penurunan fungsi imun. Salah satu manfaat dari konsumsi probiotik adalah dapat menstimulasi imunitas. Cara kerja bakteria probiotik dalam menekan pertumbuhan bakteri penyebab penyakit diawali dari pengaruh kerjanya terhadap sistem imun. ${ }^{4,12}$

Manfaat yang bisa diperoleh dari kebiasaan mengkonsumsi probiotik yaitu mampu meningkatkan pertahanan imunitas nonspesifik. Probiotik dari jenis L. casei dan $L$. bulgaricus diketahui dapat meningkatkan produksi makrofag dan mengaktifkan fagosit baik penelitian pada manusia maupun pada tikus percobaan. Proses fagositosis merupakan respon awal dari sistem pertahanan tubuh sebelum tubuh membentuk antibodi. Fagosit akan menyingkirkan agen-agen toksik yang masuk ke dalam tubuh. Hasil 
penelitian menunjukkan bahwa pemberian produk susu fermentasi yang mengandung Lactobaccillus pada penderita dermatitis atopik dan alergi terhadap susu sapi menunjukkan penurunan frekuensi diare. Penelitian lain pada tikus percobaan menunjukkan pemberian oral $B$. bifidum dan $B$. breve mampu merespon toksin cholera yang disuntikkan pada tikus tersebut. Pada penelitian ini menunjukkan peningkatkan ovalbumin dan Imunoglobulin A untuk menyingkirkan toksin cholera pada tikus. ${ }^{4}$ Penelitian lain menunjukkan probiotik ternyata mempengaruhi perubahan sistem imun di saluran cerna dan sistemik. Lactobacillus dan Bifidobacterium yang merupakan koloni terbesar di saluran cerna mampu memodifikasi reaksi yang berhubungan dengan alergi dan inflamasi. L. Casei menginduksi pembentukan IL-12 dan TGF, sedangkan $L$. reuteri menginduksi IL-10 yang berperan dalam mekanisme down regulating (menghambat produksi IL-4 dan IL-5) agar kerja sitokin tidak berlebihan.

Bifidobacterium mampu meningkatkan produksi sitokin pada orang yang sehat. Adanya ikatan antara probiotik dengan makrofag, sel dendritik, dan epitel merupakan proses penting pada sistem adesi. Dendritik dan makrofag berperan sebagai APC (antigenpresenting cell), antigen yang masuk akan diproses oleh sistem APC ini. Antigen yang telah dipresentasikan akan dibawa ke nodus limfatikus dan akan menginduksi differensiasi sel CD4 ( $\mathrm{T}$ helper). Pada keadaan alergi, sel $\mathrm{T}$ helper akan berdifferensiasi menjadi Th2 yang akan menstimulasi sekresi sitokin IL-4 dan IL-13. Sitokin ini akan menstimulasi pembentukan sel B (imunitas humoral), selanjutnya sel B akan menginduksi sekresi Ig E yang berperan dalam reaksi hipersensitivitas tipe I. Antibodi yang dihasilkan sel B akan berikatan dengan respetor IgE pada permukaan jaringan sel mast dan basofil. Sel mast dan basofil yang dilapisi oleh IgE akan tersensitisasi. Pada saat kontak ulang dengan alergen, maka alergen akan berikatan dengan IgE yang berikatan dengan antibodi di sel mastosit atau basofil dan menyebabkan granulasi. ${ }^{4}$

L. rhamnosus $R-11$ dapat menstimulasi proliferasi sel-sel epitel intestin, memberikan efek protektif terhadap penetrasi agen patogenik, dengan cara mengganti sel epitel yang rusak. Percobaan in vitro menunjukkan $L$. helveticus $R-52$ dan $L$. rhamnosus $R$ 11 dapat menginhibisi adhesi patogen (enteropatogenik E. coli O127:H6 dan enterohemoragik E. coli $\mathrm{O} 157: \mathrm{H7})$ pada sel epitel intestin, di mana kedua jenis patogen tersebut bertanggungjawab atas terjadinya diare panjang pada anak-anak dan kolitis hemoragik. Studi in vitro menunjukkan Lacidofil ${ }^{\mathrm{TM}}$ memiliki efek positif pada sel-sel imun dengan meningkatkan jumlahnya dan kemampuannya untuk melawan agen patogen intestin. $L$. helveticus $R-52$ dan $L$. rhamnosus $R-11$ secara bermakna mengaktivasi proliferasi sel-sel imun secara dose-dependent. ${ }^{13}$

Tidak terdapatnya hubungan yang signifikan antara asupan protein, vitamin $\mathrm{A}$, vitamin $\mathrm{C}$, vitamin $\mathrm{E}$, Zink dan Fe dengan limfosit secara statistik, karena status imunitas tidak hanya dipengaruhi oleh asupan makanan saja, melainkan banyak faktor lain yang dapat mempengaruhinya, seperti asupan zat gizi mikro lainnya, infeksi/penyakit, sanitasi lingkungan, pendidikan/ pengetahuan, obat-obatan, usia, aktivitas, olah raga dan stress. ${ }^{6}$ Sejalan dengan penelitian oleh Tritisari yang menilai hubungan asupan imunonutrient dan status gizi dengan angka limfosit pada lansia di Sleman, menunjukkan tidak ada perbedaan yang signifikan asupan imunonutrient terhadap penyakit infeksi. ${ }^{14}$

Tidak ada hubungan antara kualitas tidur dengan angka limfosit, berbeda dengan penelitian oleh Pittsburgh, menunjukkan bahwa gangguan tidur pada lansia dapat melemahkan sistem imun ${ }^{7}$, dengan indikator pemeriksaan sistem imun adalah sel NK.

Tidak ada hubungan antara status kesehatan dengan limfosit. Penyakit yang berhubungan dengan usia dan keadaan yang menyertai bukan hanya meningkatkan kerentanan orang lanjut usia terhadap infeksi tetapi juga dapat menekan respon imun lansia. Penyakit metabolisme dan infeksi yang menyebabkan gangguan sistem imunitas antara lain : diabetes mellitus, tuberkulosis, osteoartritis, gangguan ginjal, gangguan hati menahun. ${ }^{11}$

\section{SIMPULAN}

Disimpulkan bahwa tidak ada perbedaan yang bermakna karakteristik lansia (umur, jenis kelamin, berat badan, dan status gizi), asupan gizi (protein, vitamin $\mathrm{A}$, vitamin $\mathrm{C}$, vitamin $\mathrm{E}, \mathrm{Fe}$, Zink), kualitas tidur, dan status kesehatan fisik pada kedua kelompok. Tidak ada hubungan antara asupan gizi (protein, vitamin $\mathrm{A}$, vitamin $\mathrm{C}$, vitamin $\mathrm{E}, \mathrm{Fe}$, Zink), kualitas tidur, dan status kesehatan fisik terhadap limfosit. Terdapat pengaruh yang bermakna pemberian probiotik L. helveticusRosell-52 dan $L$. rhamnosusRosell-11 terhadap peningkatan limfosit.

\section{SARAN}

Perlu dilakukan penelitian lebih lanjut dengan mempertimbangkan faktor-faktor lain yang mempengaruhi imunitas seperti tingkat kecemasan, dan asupan zat gizi lain yang mempengaruhi imunitas pada lansia. 


\section{DAFTAR PUSTAKA}

1. Fatmah.Respons Imunitas yang Rendah pada Tubuh Manusia Usia Lanjut. $J$ Makara Kesehatan.[Online].2006;10(1):4753.URL:

http://journal.ui.ac.id/health/article/download/169 /165.[Diunduh 21 Maret 2013].

2. BPS RI. 2011. Statistik Penduduk Lanjut Usia [Online]. URL:http://www.bps.go.id/ hasil_ publikasi/stat_lansia_2011/files/search/searchtext .xml. [Diunduh 21 Maret 2013].

3. Muis. Gizi Pada Usia Lanjut. Di dalam: Matrono H. H \& Boedhi-Darmojo R, editor. Buku Ajar Geriatri : Ilmu Kesehatan Usia Lanjut. Jakarta : Balai Penerbit FKUI; 2006.

4. Widiyaningsih, EN. Peran Probiotik Untuk Kesehatan. J. Kesehatan. [Online]. 2011;4 (1),14-20.URL:http://publikasiilmiah. ums.ac.id/bitstream/handle/123456789/2931/2.\% 20ENDANG\%20NUR\%20W.pdf?sequence $=1$. [Diunduh 25 Juni 2013].

5. Panggabean, I. Hubungan Pemberian Zink dengan Hitung Limfosit dan Lama Rawat Inap pada Anak dengan Infeksi Virus Dengue di RSUD Dr. Moewardi Surakarta. J Kedokteran Indonesia. [Online]. 2011; 2(1). URL: http://jkiina.com/index.php/jki/article/view/6.

[Diunduh 22 Juni 2013].

6. Departemen Kesehatan. Riset Kesehatan Dasar (Riskesdas) 2010. Jakarta : Departemen Kesehatan RI; 2010.

7. Amran Y, Kusumawardani R, Supriyatiningsih N. Determinan Asupan Makanan Usia Lanjut (Studi di Panti Sosial Tresna Werdha Budi Mulia 01 Cipayung) [Abstrak]. J Kesehatan Masyarakat Nasional.2012; 6 (6).
8. Schlenker ED. Nutrition and The Aging Adult. Di dalam: Worthington-Roberts BS, Williams SR, editor. Nutrition Throughout The Life Cycle 3rd Edition. St Louis: Mosby-Year Book;2000.

9. Fatmah. Gizi Usia Lanjut. Jakarta : Erlangga; 2010.

10. Heffner KL, Ng HM, Suhr JA, et al. Sleep Disturbance and Older Adults Inflammatory Responses to Acute Stress. American $J$ of Geriatric Psychiatry. [Online] 2012; 20 (9); 74452. URL:http://www.ncbi.nlm.nih.gov/ pubmed/22327621. [cited Aug 15 2005].

11. Hirsch BE \& Weksler ME. Perubahan Normal pada Pertahanan Tubuh. Di dalam : Abrams WB \& Berkow R eds. Hartono A. Penerjemah. The Merck Manual of Geriatrics Jilid Dua Edisi Bahasa Indonesia. Jakarta : Binarupa Aksara; 1997.

12. Gill HS, Rutherfurd KJ, Cross ML, et al. 2001. Enhancement of Immunity in the Elderly by Dietary Supplementation with the Probiotic Bifidobacterium lactis HN019. Am J Clin Nutr.[Online] 2001; 74:833-9. URL: :http://www.ncbi.nlm.nih.gov/pubmed/11722966. [cited May 29 2013].

13. Institut Rosell - Internal Reports. (Product Monograph R-52 \& R-11). Dexa Media, J Kedokteran dan Farmasi ; 1 (20); 6-7.

14. Tritisari, Kanthi Permaningtyas. Hubungan Antara Asupan immunonutrient dan Status Gizi dengan Angka Limfosit pada Lansia di Banteng Baru, Kecamatan Ngaglik Kabupaten Sleman [Abstrak]. [Thesis]. Yogyakarta : Magister Ilmu Kesehatan Masyarakat, Universitas Gadjah Mada Yogyakarta; 2011. 